\title{
The changing pattern of miliary tuberculosis
}

\author{
J. JACQUES and J.M. SLOAN \\ Department of Pathology, The Queen's University of Belfast
}

\begin{abstract}
Over the past 20 years there has been a striking change in the clinical pattern of miliary tuberculosis, which is now more common in adults than in children. This is shown by a comparative study of the necropsy records of such cases seen in the same group of hospitals in the years 1946-9 and 1966-9. In the early period miliary tuberculosis occurred in $1.7 \%$ of necropsies, $54 \%$ of patients being under 20 years of age and suffering from a classical form of miliary tuberculosis. By $1966-9$ the incidence had fallen to $0.47 \%$ of necropsies, but now all the patients seen were over 30 years of age, the majority having a 'cryptic' clinical presentation. The percentage of patients diagnosed during life fell dramatically between the two periods and in the latter period most cases were only diagnosed at necropsy. While the incidence of childhood miliary tuberculosis has been reduced, it is now important to consider this diagnosis in adults with a variety of non-specific symptoms.
\end{abstract}

There have been disturbing reports in recent years of unsuspected miliary tuberculosis occurring, not as a classical complication of a primary childhood infection, but in a much older age group (Treip and Meyers, 1959 ; Linell and Östberg, 1966; Proudfoot, Akhtar, Douglas, and Horne, 1969). These last authors described some of the difficulties in diagnosing such cases, for the typical clinical and radiographic features of miliary tuberculosis may not be present. For this reason they introduced the term 'cryptic' miliary tuberculosis, which is characterized by an insidious onset and progression and the absence of any reliable clinical pointer to the diagnosis. Treip and Meyers (1959) stressed that such forms of tuberculosis may even be missed on naked-eye examination of the organs at necropsy, and that it is on histology alone that the final diagnosis may be made. They noted that, although the frequency of disseminated tuberculosis had fallen over the years, there was a significant rise in the number of undiagnosed cases, and an increase in the mean age of the patients affected. In a study of 6,606 necropsies in Sweden between 1960 and 1964, Linell and Östberg (1966) found 102 cases of severe active tuberculosis, and of these 21 had miliary spread. Fifteen of these cases were undiagnosed during life, the majority being over 70 years of age. Proudfoot et al. (1969) reported 40 adult cases of miliary tuberculosis, occurring over a 13-year period in Edinburgh, and of these 24 were overt while 16 fell into their 'cryptic' category. Although the symptoms and signs are usually non-specific, the importance of possible haematological manifestations, such as pancytopenia, agranulocytosis and leukaemoid reactions, has been much emphasized (O'Brien, 1954 ; Oswald, 1963 ; Eakins and Nelson, 1969). While miliary tuberculosis may complicate a chronic tuberculous focus, some adult cases arise without a well-defined origin, but there seems to be general agreement that these probably result from the reactivation of a small undiscovered quiescent lesion rather than from a primary adult infection (Myers, 1967 ; Proudfoot et al., 1969). It must be pointed out that the term 'cryptic' refers to clinical rather than pathological criteria, and that any form of tuberculosis may appear 'cryptic' in the clinical sense. We have been impressed by the occurrence recently at necropsy of several clinically unsuspected cases of miliary tuberculosis. In this paper 13 such cases, encountered during the past three years, are presented and the findings compared with cases of miliary tuberculosis seen over a similar period 20 years ago.

\section{MATERIAL}

The material used in this survey was drawn from hospital and necropsy records of patients dying of acute miliary tuberculosis in Belfast hospitals during the years 1946-9 and 1966-9. Since we have included only cases coming to post-mortem examination the figures given may well underestimate the prevalence of this condition. Furthermore, since only cases of miliary tuberculosis are included, it is necessary to 
emphasize that cases of undiagnosed tuberculosis, without miliary dissemination, are still being discovered at necropsy. During the period 1946-9, 2,274 post-mortem examinations were performed and during 1966-9, 2,700. The cases of miliary tuberculosis were studied from the standpoint of age and sex distribution, and although at times classification proved difficult an attempt was made to divide them into three types:

1. Classical acute miliary tuberculosis usually occurring in childhood as a complication of a primary infection with massive blood dissemination; 2. Miliary tuberculosis terminating a chronic tuberculous lesion, usually in the lungs or kidneys ; 3. So-called 'cryptic' miliary tuberculosis in which there was no clinically overt lesion and in which the age of the patient and the clinical findings differed from those in group 1.

It should be pointed out that 'cryptic' is not necessarily synonymous with undiagnosed, although this is frequently the case. Furthermore, since the cryptic form is not a well-defined pathological entity, it includes some cases where there appears to have been reactivation of a primary complex as well as those with a small, sometimes undetected, chronic focus.

\section{RESLLTS}

During the period 1946-9, 39 cases of miliary tuberculosis were diagnosed in our department. Figure 1 shows the age and sex distribution of these cases, of which only four, all in the adult age groups, fall into the cryptic variety. All but one of the cases under 20 years of age are of the classical type of miliary tuberculosis and the remainder represent a miliary termination of a chronic chest or renal lesion. During these years miliary tuberculosis occurred in $1.7 \%$ of necropsies in Belfast, but by 1966-9 this incidence had fallen to $0.47 \%$, for only 13 cases were discovered in the course of 2,700 necropsies. Tuberculosis was the immediate cause of death in all but one of these cases, where it was an incidental finding at necropsy. Figure 2 demonstrates the age and sex of these cases and the Table summarizes briefiy their main clinical and pathological features. The radiographic findings are included where they aided the diagnosis, but in the other cases they were either non-contributory or not carried out. There is a striking change in the age distribution and form of this disease during the past 20 years due to the almost complete abolition of death from miliary tuberculosis in childhood. In the first period the correct diagnosis was made before death in about $60 \%$ of cases, but in the latter period this was suspected in only 4 out of the 13 cases $(32 \%)$, and in none of these was it confirmed in time to initiate specific therapy. Of

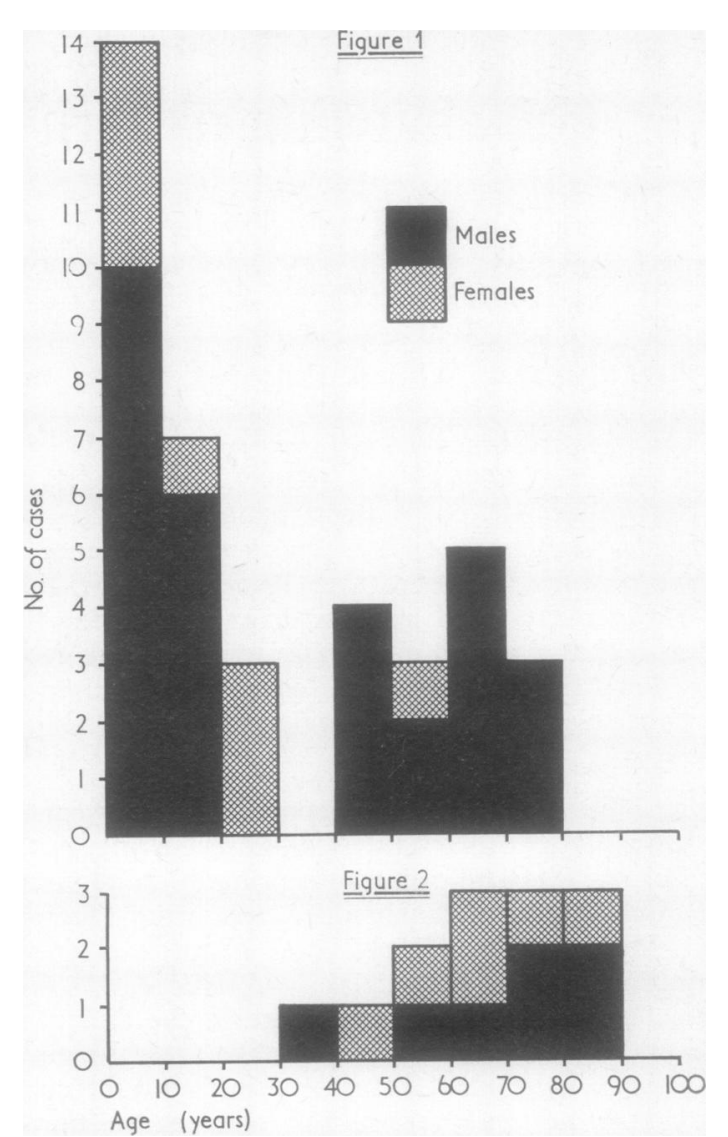

FIG. 1. Distribution of cases of miliary tuberculosis seen during the period 1946-9.

FIG. 2. Distribution of cases of miliary tuberculosis seen during the period 1966-9.

these four diagnosed cases three had an overt chronic tuberculous lesion, while the fourth developed tuberculous meningitis at the end of a 'cryptic' illness and the diagnosis was made on a biopsy of arachnoid taken during a posterior fossa exp'oration.

\section{DISCUSS:ON}

The findings presented above represent a highly satisfactory alteration in the pattern of childhood tuberculosis, deaths from which have been virtu ally eliminated over the past 20 years. It is note worthy that the period studied, 1946-9, coincides with the time of the introduction of the largescale use of BCG in this country and with the development of effective anti-tuberculosis chemotherapy. The change in the epidemiology of tuber- 
T A B L E

CLINICAL AND PATHOLOGICAL FINDINGS IN 13 CASES OF MILIARY TUBERCULOSIS SEEN BETWEEN 1966 AND 1969

\begin{tabular}{|c|c|c|c|c|c|c|}
\hline Case No. & Age & Sex & Clinical History & $\begin{array}{l}\text { Duration of } \\
\text { Illness }\end{array}$ & $\begin{array}{l}\text { Diagnosis } \\
\text { before Death }\end{array}$ & Necropsy Findings \\
\hline 1 & 32 & $\mathbf{M}$ & $\begin{array}{l}\text { Known rheumatic heart disease. } \\
\text { Pyrexia and general } \\
\text { malaise }\end{array}$ & 2 weeks & No & $\begin{array}{l}\text { Areactive miliary tuberculosis } \\
\text { (cryptic) } \\
\text { Rheumatic heart disease }\end{array}$ \\
\hline 2 & 44 & $\mathbf{F}$ & $\begin{array}{l}\text { Pyrexia and renal pain. } \\
\text { Urine-pus cells, no organisms. } \\
\text { Settled on penicillin and } \\
\text { streptomycin. Later meningitis }\end{array}$ & 5 months & $\begin{array}{l}\text { Yes } \\
\text { No therapy }\end{array}$ & $\begin{array}{l}\text { Tuberculous kidney, miliary } \\
\text { spread and tuberculous } \\
\text { meningitis (cryptic) }\end{array}$ \\
\hline 3 & 56 & $\mathbf{M}$ & $\begin{array}{l}\text { streptomycin. Later meningitis } \\
\text { Tuberculous kidneys - hydro- } \\
\text { nephrosis. Terminal bladder } \\
\text { neck obstruction }\end{array}$ & 10 months & Suspected & $\begin{array}{l}\text { Chronic tuberculosis both upper } \\
\text { lobes and kidneys. Terminal } \\
\text { miliary spread }\end{array}$ \\
\hline 4 & 59 & $\mathbf{F}$ & $\begin{array}{l}\text { Flu-like illness then recurrent } \\
\text { pulmonary emboli }\end{array}$ & 6 weeks & No & $\begin{array}{l}\text { Tuberculous adrenals, abdominal } \\
\text { nodes and miliary spread } \\
\text { (cryptic) }\end{array}$ \\
\hline 5 & 61 & $\mathbf{F}$ & $\begin{array}{l}\text { Refractory anaemia with myeloid } \\
\text { hyperplasia }\end{array}$ & 2 years & No & $\begin{array}{l}\text { Chronic lesions apices with } \\
\text { miliary spread (cryptic) }\end{array}$ \\
\hline 6 & 62 & $\mathrm{~F}$ & $\begin{array}{l}\text { Anaemia and leukopenia. } \\
\text { Leukaemoid bone marrow. } \\
\text { Given steroids }\end{array}$ & 3 months & No & $\begin{array}{l}\text { Chronic chest lesion with slight } \\
\text { miliary spread (cryptic) }\end{array}$ \\
\hline 7 & 67 & $\mathbf{M}$ & $\begin{array}{l}\text { Heavy alcohol intake-cirrhosis, } \\
\text { weight loss and abdominal } \\
\text { distension }\end{array}$ & Weeks & No & $\begin{array}{l}\text { Active lesion lung with miliary } \\
\text { spread } \\
\text { Cirrhosis }\end{array}$ \\
\hline 8 & 72 & $\mathbf{F}$ & $\begin{array}{l}\text { Rheumatoid arthritis. } \\
2 \text { weeks' history of anorexia } \\
\text { and cough. } \\
\text { Recent weight loss. } \\
\text { Put on steroids after admission }\end{array}$ & 1 month & No & $\begin{array}{l}\text { Areactive miliary tuberculosis, } \\
\text { miliary spread (cryptic) } \\
\text { Cirrhosis }\end{array}$ \\
\hline 9 & 75 & $\mathbf{M}$ & $\begin{array}{l}\text { Retention of urine-enlarged } \\
\text { prostate. } \\
\text { Collapsed after admission }\end{array}$ & 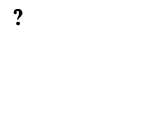 & No & $\begin{array}{l}\text { Chronic lung lesion with } \\
\text { miliary termination } \\
\text { Benign nodular hyperplasia } \\
\text { prostate with retention of } \\
\text { urine }\end{array}$ \\
\hline 10 & 79 & $\mathbf{M}$ & Discharging sinus on scrotum & Few months & Yes & $\begin{array}{l}\text { Progressive tuberculosis of } \\
\text { epididymis with miliary } \\
\text { tuberculosis, areactive }\end{array}$ \\
\hline 11 & 83 & $\mathbf{M}$ & $\begin{array}{l}\text { Dysphagia and subphrenic abscess. } \\
\text { Chest radiographs miliary } \\
\text { mottling }\end{array}$ & 1 month & No & $\begin{array}{l}\text { Active lung lesion with } \\
\text { oesophagitis, subphrenic abscess } \\
\text { and miliary spread }\end{array}$ \\
\hline 12 & 87 & $\mathbf{M}$ & $\begin{array}{l}\text { Pyrexia. } \\
\text { Chest radiograph-active apical } \\
\text { tuberculosis }\end{array}$ & 3 weeks & Yes & $\begin{array}{l}\text { Active chest lesion with } \\
\text { miliary termination }\end{array}$ \\
\hline 13 & 85 & $\mathbf{F}$ & $\begin{array}{l}\text { tuberculosis } \\
\text { Hemiplegia - died } 3 \mathrm{hrs} \text { later }\end{array}$ & ? & No & $\begin{array}{l}\text { Infarct cerebral hemisphere } \\
\text { Tuberculosis adrenals and lymph } \\
\text { nodes with miliary spread } \\
\text { (cryptic) }\end{array}$ \\
\hline
\end{tabular}

culosis is largely the result of these two factors. The above results, however, are more disappointing where adult tuberculosis is concerned, and the low rate of diagnosis among this group is even more disturbing. It is undoubtedly true that the symptomatology and clinical findings may be far from helpful, a factor which adds to the problem. The majority of cases of miliary tuberculosis seen today are complications of a chronic lesion which is usually in the lungs. In this series, however, two cases (Nos 1 and 7) were found in which no disseminating focus of infection was discovered. In these it is more than likely that the miliary spread resulted from reactivation of a small quiescent, chronic lesion rather than from an undiscovered primary focus. From a clinical standpoint the term 'cryptic' introduced by Proudfoot et al. (1969) does have some justification and has been applied to 11 cases in the course of this study, but pathologically the dissemination can stem from a reactivated primary complex, or a chronic tuber- culous lesion, or, as mentioned in two cases, it may arise from an undiscovered source. The term can therefore be considered valid only in so far as it emphasizes the diagnostic difficulty associated with many cases of adult tuberculosis. It certainly does not correspond to any welldefined pathological pattern.

Böttiger, Nordenstam, and Webster (1962) stressed the danger of the indiscriminate use of cortisone in elderly patients and cited three patients with miliary tuberculosis who had been given steroids before a firm diagnosis had been made. Only 2 of the 13 cases presented here received steroids, and these drugs cannot, therefore, be directly incriminated in the majority of cases of miliary tuberculosis. This, however, in no way detracts from the dangers of steroid therapy in patients with tuberculosis. It is interesting that the patients who received steroids had an areactive form of tuberculosis, characterized by much caseation and many tubercle bacilli, with a poor 
surrounding cellular response, and this pattern was repeated in two patients not on steroids. This type of reaction probably represents a low degree of resistance to infection rather than increased virulence of the organism.

The haematological manifestations of tuberculosis have been emphasized by O'Brien (1954) and by Eakins and Nelson (1969), who reported six cases of tuberculosis from this centre presenting as a haematological problem. This is uncommon however, and only two cases in the present series fall into this category. The most usual clinical findings are of an ill patient with a vague pyrexial illness and largely negative results on investigation. It is disturbing to think that there remains in the population, especially among the elderly, a small pocket of active communicable tuberculosis: it is salutary to remember that the number of cases of miliary tuberculosis seen at necropsy in this department still exceeds that of often sus- pected conditions like polyarteritis nodosa and systemic lupus erythematosus.

We wish to express our thanks to Professor Sir John Biggart for permitting us to use the extensive records of his department and to Professor Florence McKeown for her suggestions in the preparation of the manuscript.

\section{REFERENCES}

Böttiger, L. E., Nordenstam, H. H., and Webster, P. O. (1962). Disseminated tuberculosis as a cause of fever of obscure origin. Lancet, 1, 19.

Eakins, D., and Nelson, M. G. (1969). Disseminated tuberculosis with associated haematological disorders. Irish J. med. Sci., $2,79$.

Linell, F., and Östberg, G. (1966). Tuberculosis in an autopsy material. Scand. J. resp. Dis., 47, 200.

Myers, J. A. (1967). Tuberculosis in the aged. Postgrad. Med., 41, 214. O'Brien, J. R. (1954). Non-reactive tuberculosis. J. clin. Path., 7, 216.

Oswald, N. C. (1963). Acute tuberculosis and granulocytic disorders. Brit. med. J., 2, 1489.

Proudfoot, A. T., Akhtar, A. J., Douglas, A. C., and Horne, N. W. (1969). Miliary tuberculosis in adults. Ibid., 2, 273.

Treip, C., and Meyers, D. (1959). Fatal tuberculosis in a general hospital. A diagnostic problem. Lancet, 1, 164 . 